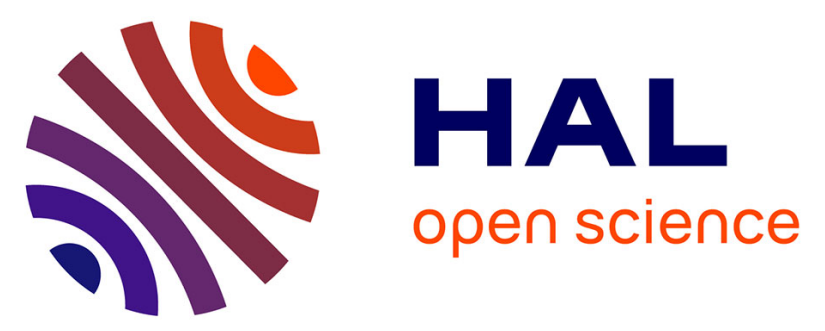

\title{
Evidence for TiO2 nanoparticle transfer in a hard-rock aquifer
}

\author{
Lise Cary, Hélène Pauwels, Patrick Ollivier, Géraldine Picot-Colbeaux, \\ Philippe Leroy, Bruno Mougin, Gilles Braibant, Jérôme Labille
}

\section{> To cite this version:}

Lise Cary, Hélène Pauwels, Patrick Ollivier, Géraldine Picot-Colbeaux, Philippe Leroy, et al.. Evidence for $\mathrm{TiO} 2$ nanoparticle transfer in a hard-rock aquifer. Journal of Contaminant Hydrology, 2015, 179, pp.148-159. 10.1016/j.jconhyd.2015.06.007 . hal-01169974

\section{HAL Id: hal-01169974 https://hal-brgm.archives-ouvertes.fr/hal-01169974}

Submitted on 30 Jun 2015

HAL is a multi-disciplinary open access archive for the deposit and dissemination of scientific research documents, whether they are published or not. The documents may come from teaching and research institutions in France or abroad, or from public or private research centers.
L'archive ouverte pluridisciplinaire HAL, est destinée au dépôt et à la diffusion de documents scientifiques de niveau recherche, publiés ou non, émanant des établissements d'enseignement et de recherche français ou étrangers, des laboratoires publics ou privés. 
Evidence for $\mathrm{TiO}_{2}$ nanoparticle transfer in a hard-rock aquifer

Lise Cary ${ }^{1, *}$, Hélène Pauwels ${ }^{1}$, Patrick Ollivier ${ }^{1}$, Géraldine Picot ${ }^{1}$, Philippe Leroy ${ }^{1}$, Bruno Mougin $^{2}$, Gilles Braibant ${ }^{1}$, Jérôme Labille ${ }^{3}$

${ }^{1}$ BRGM, 3 avenue C. Guillemin, BP 6009, 45060 Orléans, France ${ }^{2}$ BRGM Service Géologique Régional Bretagne, 2 rue de Jouanet, 35700 Rennes, France ${ }^{3}$ Aix-Marseille Université,CNRS, IRD, CEREGE UM 34, Aix-en-Provence 13545, France

*Corresponding author: Phone number: 00332386432 60; e-mail: I.cary@brgm.fr Intended for publication in Journal of Contaminant Hydrology

Abstract

Water flow and $\mathrm{TiO}_{2}$ nanoparticle (NP) transfer in a fractured hard-rock aquifer were studied in a tracer test experiment at a pilot site in Brittany, France. Results from the $\mathrm{Br}$ tracer test show that the schist aquifer can be represented by a two-layermedium comprising i) fractures with low longitudinal dispersivity in which water and solute transport is relatively fast, and ii) a network of small fissures with high longitudinal dispersivity in which transport is slower. Although a large amount of NPs was retained within the aquifer, a significant $\mathrm{TiO}_{2}$ concentration was measuredin a well $15 \mathrm{~m}$ downstream of the NP injection well, clearly confirming the potential for $\mathrm{TiO}_{2} \mathrm{NPs}$ to be transported in groundwater. The Ti concentration profile in the downstream well was modelled using a two-layermedium approach. The delay used for the $\mathrm{TiO}_{2}$ NPs simulation compared to the $\mathrm{Br}$ concentration profiles in the downstream well indicate that the aggregated $\mathrm{TiO}_{2} \mathrm{NPs}$ interacted with the rock. Unlike $\mathrm{Br}$, NPs do not penetrate the entire pore network during transfer because of electrostatic interactions between NP aggregates and the rockand also to the aggregate size and the 
hydrodynamic conditions, especially where the porosity is very low;NPs with a weak negative charge can be attachedonto the rock surface, and more particularly onto the positively charged iron oxyhydroxides coating the main pathways due to natural denitrification. Nevertheless, $\mathrm{TiO}_{2}$ NPs are mobile and transfer within fracture and fissure media. Any modification of the aquifer's chemical conditions is likely to impact the groundwater $\mathrm{pH}$ and, the nitrate content and the denitrification process, and thus affect NP aggregation and attachment.

Highlights

A study of $\mathrm{TiO}_{2} \mathrm{NP}$ transfer at a pilot site in a hard-rock aquifer.

The $\mathrm{TiO}_{2} \mathrm{NPs}$ were mobile in the schist aquifer and transferred in aggregate form.

Unlike $\mathrm{Br}$, NPs do not penetrate the entire pore network during transfer.

A large amount of NPs was deposited on the aquifer walls in the flow pathways.

Any modification of the aquifer's chemical condition will impact NP aggregation and sorption.

Keywords: $\mathrm{TiO}_{2}$ nanoparticles, groundwater, hard-rock aquifer, transfer, zeta potential, $\mathrm{pH}_{\mathrm{PZC}}$, field tracer test 


\section{Introduction}

Not only are $\mathrm{TiO}_{2}$ nanoparticles (NPs) nowadays one of the most widely produced NPs by weight with,for example, 4 million metric tons of $\mathrm{TiO}_{2} \mathrm{NPs}$ being manufactured worldwide in 2006 (Robichaud et al., 2009), butthe range of their application has expanded very rapidly over the past decade. Due to their photocatalytic activity (Gaya and Abdullaha, 2008), high refractive index, high specific surface area and sorption capacity for ionic and non-ionic species, $\mathrm{TiO}_{2}$ NPs are currently used for industrial and household purposes such as photovoltaics, ultraviolet blocking sunscreens, self-cleaning surfaces (such as glass), and antimicrobial, antibiotic and antifungal agents. They are also used as a scavenger of inorganic and organic contaminants in water treatment plants and for the remediation of polluted subsurface environments (Pena et al., 2006).

The increasing use of $\mathrm{TiO}_{2} \mathrm{NPs}$ is inevitably leading to its introduction into different environmental compartments, including soil, surface water and groundwater (Ben-Moshe et al., 2010; Chen et al., 2011; Fang et al., 2013; Holbrook et al., 2013; Johnson et al., 2011; Lin et al., 2010; Lowry et al., 2010; Reijnders, 2009).Anticipated groundwater contamination by NPs and their related by-products is expected to occur in different ways, including accidental events, inappropriate storage of nano-waste, normal aging during regular use, soil leaching and infiltration after spreading sludge from wastewater treatment, during groundwater/surface water exchanges and even by direct injection as for remediation purposes (Bennett et al., 2010; Elliott and Zhang, 2001; Gondikas et al., 2014; Holbrook et al., 2013; Su et al., 2013). The spread of makeup and sunscreens into surface waters and swimming pools has been observed to be responsible for the presence of significant concentrations of manufactured $\mathrm{TiO}_{2} \mathrm{NPs}$ in the water (typically $>1 \mu \mathrm{g}$ NP per litre of water [Kaegi et al., 2008]). $\mathrm{TiO}_{2} \mathrm{NPs}$, however, have been classified as potentially cancerous for humans by the International Agency for Research on Cancer (IARC, 2006), so where groundwater is widely used for drinking water, any contamination could have an adverse impact on human health.The adverse impact of these NPs has already been shown on 
bacteria (Santaella et al., 2014), crustaceans (Fouqueray et al., 2013), mice (Liu et al., 2009; Ma et al., 2009), plants and human lymphocytes (Ghosh et al., 2010). Consequently, the potential exposure of $\mathrm{TiO}_{2} \mathrm{NPs}$ through groundwater contamination needs to be studied and assessed.

NPs are characterized by a high surface charge density and a very high surface area to volume ratio (Leroy et al., 2011; Petosa et al., 2010; Wiesner et al., 2006), with the result that electrostatic interactions between NPs themselves and between NPs and the surrounding geogenic material control the complex processes that regulate NP transport and deposition in natural water (Moore, 2006; Wiesner et al., 2006). Their environmental fate, however, is highly dependent on their volume fraction in water, on their intrinsic properties such as solubility, surface properties, zero point charge $\mathrm{pH}\left(\mathrm{pH}_{z \mathrm{pc}}\right)$, surface area, crystallinity, shape and size, as well as on the groundwater's overall physical and chemical properties (Auffan et al., 2009; Brant et al., 2005; Chen et al., 2012; French et al., 2009; Godinez and Darnault, 2011; Guzman et al., 2006; Keller et al., 2010; Petosa et al., 2012; Shih et al., 2012; Zhang et al., 2009). Since NPs are rarely in a perfectly dispersed state in natural water (Keller et al., 2010), their transport behaviour is also dependent on the formation and eventual break-up of NP aggregates, which are influenced by the flow velocity and interaction energies between particles (Brant et al., 2005; Fang et al., 2013; Godinez and Darnault, 2011).

In porous media, NP mobility is controlled by the reactive transport properties that affect NP-rock interactions (Petosa et al., 2010; Solovitch et al., 2010; Tufenkji and Elimelech, 2004); depending on the rock's surface charge and the flow rate, dispersed nanoparticles can be adsorbed or repulsed in the vicinity of mineral grains. In addition, the rock's permeability, plus the pore size and organization, will also affect aggregate transport and deposition. $\mathrm{TiO}_{2}$ NPs aggregates are clearly shown to remain mobile in artificial porous media despite their aggregation under a wide range of physical and chemical conditions (Guzman et al., 2006), but few studies (French et al., 2009; Keller et al., 2010)have been 
dedicated to $\mathrm{TiO}_{2} \mathrm{NP}$ transfer in groundwater along with the wide range of natural physical and chemical conditions.

Hard-rock aquifers contain major water resourcesand their vulnerability to pollutionis a crucial issue (Ayraud et al., 2008; Jaunat et al., 2012; Guihéneuf et al., 2014;Pauwels et al., 2015, among others). The purpose of our study is to investigate the potential transfer of $\mathrm{TiO}_{2}$ NPs in a hard-rock aquifer whosefracture connectivity determines the main pathways for groundwater flow and whose low ionic strengthis expected to influence the NPs transport. The groundwater's low organic content at the study site is expected to limit NP aggregation,with the precipitation of Fe oxyhydroxides in the main pathways after natural denitrification being the main process affecting NP transport. To the best of our knowledge, there has so far been no attempt to quantify the mobility of $\mathrm{TiO}_{2} \mathrm{NPs}$ in a hard-rock schist aquifer through an experimental tracer test at a pilot site. Here, we studied the transfer of $\mathrm{TiO}_{2}$ NPs through a schist aquifer, monitoring the NPs within both the injection and pumping wells.

\section{Site description}

The pilot site, located in thesmall Naizincatchment $85 \mathrm{~km}$ west of Rennes in Brittany (France), is underlain by a Precambrian (Brioverian, $530 \mathrm{Ma}$ )schist aquifer (Pellerin and Van Vliet-Lanoe, 1994). The basin's hydrogeological system is influenced by the presence of two aquifer compartments, resulting in a variable hydraulic conductivity and porosity (Fig. 1): (1) the saprolite, or weathered layerfrom the surface to $15 \mathrm{~m}$ depth and overlain by surficial formations (soil and alluvial deposits), is a clay-rich facieswith a mostly interstitial porosity ensuring the storage function of the aquifercompartment, and (2) the underlying weatheredfissured zone, showing a lesser degree of weathering and with a dense horizontal fissuring,grading down into the deep fresh and fractured rock ensuring the transmissive function of the aquifer. The main permeability in this medium, which can be represented as a dual porosity system, is related to tectonic fractures (Martelat and Lachassagne, 1995) 
regionally inherited from Hercynian and Alpine orogeneses, and it is the fracture connectivity that mainly controls groundwater flow (Dewandel et al., 2006; Maréchal et al., 2004).

Groundwater abstraction in the catchmentconsists of rare agricultural pumpingand can be considered negligible compared to the annual recharge (319 $\mathrm{mm}$ per year of effective rainfall).The global groundwater flow direction is from the plateau to the river (from DNS1 to F1) and is completed by a vertical component from the depth to the surface, and to the river. In periods of low water levelssuch as the period of the test, water flows downward (Pauwels et al., 2000).

The groundwater's chemical composition at the site has been extensively described. Itshows a strong variability from the surface to $15 \mathrm{~m}$ depth due to intensive agricultural activity (Pauwels et al., 2000), whilstin the underlying fissured schist it results from a mixing between old water and recent denitrified groundwater from the overlying weathered layer (Ayraud et al., 2008). The groundwater in the underlying fissured schistshows a weak mineralization (ionic strength of $3 \cdot 10^{-3}$ mol. $\mathrm{L}^{-1}$ ), near neutral $\mathrm{pH}$ conditions (6.5 to 7.0 ) and reductive conditions with a low oxygen content;itslow organic content originates from reaction with oxygen during its passage through the upper soil and weathered layer. The groundwater in the schist compartment also appears to be totally denitrified through microbial autotrophic denitrification between nitrate and pyrite, leading to the production of Fe (II) and subsequent precipitation of Fe (III) hydroxides or oxides (Boisson et al., 2013; Pauwels et al., 1998; Tarits et al., 2006)thatcan strongly interact with NPs (Dzombak and Morel, 1990).

\section{Material and methods}

\subsection{Aquifer characterization}

The schist, in decreasing relative mass proportions, consists mainly of quartz, muscovite, chlorite and, to a lesser extent, K-feldspar and plagioclase. Pyrite is the main accessory 
mineral below $7 \mathrm{~m}$ depth and varies between $0.3 \%$ and $5.0 \%$ of the dry rock weight. Secondary phases include illite, smectite, kaolinite and various Fe-oxyhydroxides (e.g. hematite and goethite) and sulphate phases such as jarosite(Pauwels et al., 1998).

The apparent zeta potential (Bouhaik et al., 2013; Crespy et al., 2007; Leroy et al., 2011) of the schist was measured in the laboratory using streaming potential measurements (ZetaCad, CAD Instruments, France) at a $\mathrm{pH}$ and ionic strength (IS) close to the natural conditions of the study site's groundwater (i.e. $\mathrm{pH} 6$ and 7 , and IS $=1.5 \cdot 10^{-3} \mathrm{M}$ ), and using $\mathrm{HCl}$ or $\mathrm{NaOH}$ for $\mathrm{pH}$ adjustment. The $\mathrm{NaCl}$ and $\mathrm{CaCl}_{2}$ concentrations were respectively 0.70 and $0.28 \mathrm{mM}$. The measured apparent zeta potential was slightly negative $(-6.3 \mathrm{mV}$ at $\mathrm{pH} 6$ and $-6.1 \mathrm{mV}$ at $\mathrm{pH} 7)$. Although the schist'smineral compositionis heterogeneous, its surface charge is controlled by the quartz and phyllosilicates. Note that the magnitude of the schist's apparent zeta potential is low, probably because of the presence of ionized $\mathrm{Ca}$ at twice the positive charge of the ionized $\mathrm{Na}$.

\section{2 $\mathrm{TiO}_{2}$ Nanoparticle characterization}

The $\mathrm{TiO}_{2}$ NPs used in this study (stock number 39953, anatase, Alfa Aeasar, 32 nm; see Solovitch et al., 2010)consistedofballs with diameters ranging from 10 to $50 \mathrm{~nm}$,but capable of forming aggregatesaround $100 \mathrm{~nm}$ in sizeas observed by TEM (Hitachi S4500, SEB) on dry powdered $\mathrm{TiO}_{2}$. XRD analysis (automatized Siemens D5000 diffractometer) showed anatase, a $\mathrm{TiO}_{2}$ mineral, with trace quantities of rutile. The specific surface area of the $\mathrm{TiO}_{2}$ NPs determined by BET analysis (Tristar 3000, Micromeritics) was $47.6 \mathrm{~m}^{2} \cdot \mathrm{g}^{-1}$, consistent with the $52 \mathrm{~m}^{2} \cdot \mathrm{g}^{-1}$ value given by the supplier.

Aggregation tests were conducted in the laboratory to better foresee the NPs aggregation rateaccording to their concentration in contact with MilliQ water and the schist's groundwaterpreviously collected and kept in natural conditions (atmosphere-free) and with ultrasonification or not. The $\mathrm{pH}$ corresponding to $\mathrm{a} \mathrm{TiO}_{2}$ electrophoretic mobility of zero, $\mathrm{pH}_{\mathrm{IEP}}$ (isoelectric point $\mathrm{pH}$ ), was $5.5 \pm 0.1$ (Solovitch et al., 2010). On site, the $\mathrm{TiO}_{2} \mathrm{NPs}(200 \mathrm{~g}$ ) 
were added to $30 \mathrm{~L}$ of groundwater. To prevent the NPs' time-dependent aggregation phenomenon, the NP suspension was injected into Well F1 very shortly( $1 \mathrm{~h})$ after its preparation. The size and zeta potential of the $\mathrm{TiO}_{2} \mathrm{NPs}$ were measured on site immediately after mixing with thegroundwater sample prior to injection, and also throughout the experiment; the apparent zeta potentialwas determined by electrophoretic mobility measurements using a zetasizerNanoZS (Malvern Instruments). The uncertainty was +/- 3 $\mathrm{mV}$ on 3 measures. The average hydrodynamic aggregate diameter was also measured on site using a zetasizerNanoZSwith the Dynamic Light Scattering (DLS) method. The polydispersity index (Pdl) was used as an indicator of the distribution width. The derived count rate indicating the intensity of light scattered by the particles was used to follow the relative evolution of particle concentration in the sampled water.

\subsection{Transfer test design}

The test consisted in first injectinga conservative tracer solution $(\mathrm{NaBr})$ and then the $\mathrm{TiO}_{2}$ NP suspension directly into the groundwater in order to compare their respective transfers. The pilot test experiment,outlined in Fig. 1, was conducted using stabilized and continuous pumping between the injection well, F1, and the downstream pumping well, DNS1, where the flow rate was stabilized at $2.46 \cdot 10^{-4} \mathrm{~m}^{3} \cdot \mathrm{s}^{-1}$ (except during two short electricity cuts caused by thunderstorms). The upstream injection well F1 is $82 \mathrm{~m}$ deep and is screened between 32 and $82 \mathrm{~m}$ depth, whichrepresentsthe fissured and unweathered part of the aquifer with a more permeable fracture zone at $70 \mathrm{~m}$ depth. The pumping well DNS1, located $15 \mathrm{~m}$ downstream from $\mathrm{F} 1$, is $97 \mathrm{~m}$ deep and screened between 1 and $97 \mathrm{~m}$. The groundwater level in DNS1 was first stabilized by pumping for four days at $2.44 \cdot 10^{-4} \mathrm{~m}^{3} \cdot \mathrm{s}^{-1}$, after which the groundwater came mainly from fracture flow with a partial contribution through leaching from the surficial horizons (Pauwels et al., 2000). The natural $\mathrm{Na}$ and $\mathrm{Br}$ concentrations measured in Well $\mathrm{F} 1$ before the injection of the $\mathrm{NaBr}$ solution were 0.7 and $3.0 \mu \mathrm{mol} . \mathrm{L}^{-1}$, respectively; the conservative NaBrtracer and the $\mathrm{TiO}_{2} \mathrm{NPs}$ were then diluted with water collected 
fromwell $\mathrm{F} 1-3 \mathrm{~kg}$ of $\mathrm{NaBr}$ in $50 \mathrm{~L}$ and $200 \mathrm{~g}$ of $\mathrm{TiO}_{2} \mathrm{NPs}$ in $30 \mathrm{~L}$. To avoid any $\mathrm{TiO}_{2}$ aggregation due to the increased ionic strength induced by the presence of high $\mathrm{Na}^{+}$and $\mathrm{Br}^{-}$ concentrations resulting from the $\mathrm{NaBr}$ injection, a six-day delay was applied between the NaBrinjection and the $\mathrm{TiO}_{2} \mathrm{NP}$ injection to ensure a $\mathrm{Br}$ concentration low enough not to influence the groundwater's ionic strength. Continuous mixing of the water within the injection well $\mathrm{F} 1$ throughout the test period was ensured by recirculation (pumping at $1.4 \cdot 10^{-3} \mathrm{~m}^{3} \cdot \mathrm{s}^{-1}$ and re-injection) between 6 and $70 \mathrm{~m}$ depth so as to avoid sedimentation at the bottom of the piezometer. According to the volume of water recirculating $\left(0.63 \mathrm{~m}^{3}\right)$ in the well between 6 and $70 \mathrm{~m}$ depth, and assuming that the mixing along the water column due to the pumping and re-injection was instantaneous, the concentrations of $\mathrm{Br}$ and $\mathrm{Ti}$ just after their injection were calculated to be $45 \mathrm{mmol} . \mathrm{L}^{-1}\left(3.6 \mathrm{~g} . \mathrm{L}^{-1}\right)$ and $3.8 \mathrm{mmol} . \mathrm{L}^{-1}\left(182 \mathrm{mg} . \mathrm{L}^{-1}\right)$, respectively. These concentrations correspond to a point-source pollution context (industrial accident during production, accident during transportation...).

\subsection{Water sampling and analysis}

The groundwater chemistry was analysed in the injection and downstream wells before the experiment for cations, anions and dissolved and total organic carbon (DOC and TOC), and during the experiment for $\mathrm{Br}$ and $\mathrm{Ti}$. The groundwater in the injection well was sampled $16 \mathrm{~h}$ after the NP injection, whilst the physical and chemical parameters and the zeta potential and electrophoretic mobility were monitored throughout the experiment to check the evolution of the NP suspension. After each injection, the groundwater was sampled from the pumping well DNS1;during the day this was done manually every hour for the first 4 hours of the experiment, and then manually every 4 hours for the next 7 days, and at night byautomatic sampler every 4 hours for the following 7 nights. A total of 74 samples was analysed for $\mathrm{Br}$. Sampling for the $\mathrm{TiO}_{2} \mathrm{NPs}$ was undertaken every $12 \mathrm{~h}$ from day 6 to day 15 and then every $24 \mathrm{~h}$ from day 16 to day 30; a total of 40 samples was selected for Ti analysis.Measurements of the physical and chemical parameters (temperature, electricalconductivity [EC], $\mathrm{pH}$, 
oxidation- reduction potential, and dissolved oxygen) were made in situin the field,using probes throughout the experimentjust after sampling.

For further chemical analysis, the groundwater samples were filtered in the field through $0.45 \mu \mathrm{m}$ cellulose acetate filters. Those for cation analysis were then acidified by $\mathrm{HNO}_{3}$ at $\mathrm{pH}$ 2, whilst those for anion analysis were stored without acidification. The analyses for $\mathrm{Ca}^{2+}$, $\mathrm{Mg}^{2+}, \mathrm{Na}^{+}$and $\mathrm{K}^{+}$were carried out by inductively coupled plasma-atomic emission spectroscopy (ICP-AES, Ultima-2 model, JobinYvon), and those forCl', $\mathrm{SO}_{4}{ }^{2-}$ and $\mathrm{NO}_{3}{ }^{-}$by ion chromatography (model DX120, Dionex). The accuracy of both techniques was greater than5 $\%$, depending upon the concentration. The alkalinity was measured on site by titration with $\mathrm{HCl}$, and the equivalent point was determined by the Gran method. Aliquots (50 $\mathrm{mL})$ for $\mathrm{Br}$ measurement were filtered through $0.2 \mu \mathrm{m}$ filters, with the $\mathrm{Br}^{-}$concentration being determined firstly on site with a Br-electrode, and later in the laboratory by ionic chromatography (Dionex) with a $5 \%$ uncertainty; the quantification limit (QL) was $1 \cdot 10^{-3}$ mmol. $\mathrm{L}^{-1}$. Aliquots $(50 \mathrm{~mL})$ for $\mathrm{Ti}$ measurement were acidified to $\mathrm{pH} 2$ with suprapur $\mathrm{HNO}_{3}$, the Ticoncentration being determined by ICP-MS ata detection limit of $0.004 \mu \mathrm{M}$. $\mathrm{TiO}_{2}$ NP standards were prepared using $\mathrm{TiO}_{2}$ anatase NPs diluted with natural water from the aquifer. The correlation line between the NP-defined standards and the measured Ti concentrations was good $\left(r^{2}=0.90\right)$. For total organic carbon (TOC) and dissolved organic carbon (DOC) analyses, respectively, unfiltered and filtered water was collected in brown glass bottles and acidified with $\mathrm{H}_{2} \mathrm{SO}_{4}$; the TOC and DOC were analysed by oxidation with sodium persulphate.

Despite anaerobic conditions having been characterized in both wells, the pumping in Well DNS1 induced mixing with oxygenated waterfrom the surficial weathered layer, thus enhancing the natural partial contribution by leakage of the surficial horizons due to the downward flow. It thus favored local transient aerobic conditions. Nevertheless, $\mathrm{TiO}_{2} \mathrm{NPs}$ are not affected by groundwater oxido-reductive conditions. Before the experiment, the groundwater $\mathrm{pH}$ was sub-neutral (6.94 in Well F1 and 6.54 in Well DNS1) and its 
electricalconductivity was low $(225 \mu \mathrm{S} / \mathrm{cm}$ in $\mathrm{F} 1$ and $210 \mu \mathrm{S} / \mathrm{cm}$ in DNS1, Table 1). The dominant cations for wells $\mathrm{F} 1$ and DNS1, respectively, were $\mathrm{Na}^{+}\left(0.70\right.$ and $\left.0.75 \mathrm{mmol} . \mathrm{L}^{-1}\right)$ followed by $\mathrm{Mg}^{2+}\left(0.40\right.$ and $\left.0.38 \mathrm{mmol} . \mathrm{L}^{-1}\right)$ and $\mathrm{Ca}^{2+}\left(0.31\right.$ and0.24 mmol. $\left.\mathrm{L}^{-1}\right)$, with $\mathrm{Cl}^{-}$ (0.72and0.76 mmol. $\left.\mathrm{L}^{-1}\right)$ and $\mathrm{SO}_{4}{ }^{2-}\left(0.25\right.$ and $\left.0.28 \mathrm{mmol} . \mathrm{L}^{-1}\right)$ beingthe dominant anions; alkalinity was low $\left(0.7\right.$ to 1.0 meq. $\left.\mathrm{L}^{-1}\right)$. The $\mathrm{NO}_{3}{ }^{-}$content was very low (respectively below the quantification limit $[Q L]$ and 0.034 mmol. $\mathrm{L}^{-1}$ ) due to denitrification (Pauwels et al., 2000). The $\mathrm{Br}^{-}$content was respectively 3.7 and $3.0 \mu \mathrm{mol}^{-L^{-1}}$ for Well F1 and Well DNS1 (Table 1), with a geochemical background value at $3.2 \mu \mathrm{mol} . \mathrm{L}^{-1}$. The ionic strength was $3 \cdot 10^{-3} \mathrm{M}$, indicating a low mineralization of water as previously shown by Pauwels et al. (2000). The Ti concentrations before the experiment were equal to the $\mathrm{QL}\left(0.002 \mu \mathrm{mol} . \mathrm{L}^{-1}\right)$ in both wells. TOC and DOC were generally low, although slightly higher in Well F1 (respectively 0.20 and $\left.0.14 \mathrm{mmol} \mathrm{C.L} \mathrm{L}^{-1}\right)$ than in Well DNS1 $(<Q L)$.

\subsection{Modelling tool}

Modelling the $\mathrm{Br}$ and $\mathrm{TiO}_{2}$ recovery was done using CATTI (Computer Aided Tracer Test Interpretation) software (Sauty, 1989) and assuming radial convergent flow between the upstream and downstream wells along withinstantaneous tracer injection and recirculation. The flow and solute transports were modelled assuming that the aquifer was homogeneous and horizontally infinite. In addition we considered that the tracer,under the predominant influence of the hydraulic gradient imposed by pumping in Well DNS1, propagated through two different media of contrasted porosities and dispersivities and that the flow rate was constant.The two media will be hereafter referred to as the fissured medium with slow transport and the fractured medium with fast transport. 
The transport parameters, i.e. the effective porosity and the longitudinal dispersivity of each medium, were estimated by fitting the calculated conservative solute breakthrough curve to the $\mathrm{Br}$ experimental breakthrough curve (BTC) using the CATTI's automatic identification tool based on non-linear least squares estimation methods. Different initial values of parameters were tested to find the best fitted parameters. The selected ones were the best we could find corresponding to the highest mass recovery. But because, in the case of a radial converging flow and transport, no analytical solution existsto exactly calculate the solute concentration in the downstream well at a given time after injection (Sauty, 1989), an approximate solution can be used to estimate the solute concentration with time as long as the Peclet number $(\mathrm{Pe})$ is high enough $(>2)$.

Here, $P e=\frac{r}{\alpha}$ which gives $\mathrm{Pe} \approx 9.4$ for the fractured medium $(\mathrm{F})$ and $P e \approx 6$ for the fissured medium (f) (Sauty et al., 1992). The approximate solution, where the second and third terms correspond to the concentration in the fractured and fissured media respectively, is:

$$
C(r, t)=C_{i}+\frac{\Delta M_{F} r}{2 Q_{F} \sqrt{\pi D_{L F}} t^{3 / 2}} \exp \left(-\frac{\left(r-u_{F} t\right)^{2}}{4 D_{L F} t}\right) \exp (-\lambda t)+\frac{\Delta M_{f} r}{2 Q_{f} \sqrt{\pi D_{L f}} t^{3 / 2}} \exp \left(-\frac{\left(r-u_{f} t\right)^{2}}{4 D_{L f} t}\right) \exp (-\lambda t)
$$

where $\mathrm{C}$ is the solute concentration, $\mathrm{C}_{\mathrm{i}}$ the solute geochemical background concentration $\left[\mathrm{kg} \cdot \mathrm{m}^{3}\right], r$ the radial distance between the injection and pumping wells $[\mathrm{m}], \mathrm{t}$ the time $[\mathrm{s}], \Delta \mathrm{M}$ the injected mass in each layer[kg],

$Q$ the pumping rate of the downstream well passing through each layer $\left(Q_{F}\right.$ and $Q_{f}$ for the fractured and fissured media respectively) $\left[\mathrm{m}^{3} . \mathrm{s}^{-1}\right], \lambda$ the decay rate $\left[\mathrm{s}^{-1}\right]$ characterised as an exponential decrease function of the shape $e^{-\lambda t}$,

$D_{L}$ the longitudinal dispersion coefficient $\left[m^{2} . s^{-1}\right]$ where $D_{L}=\alpha_{L} u$, with $\alpha_{L}$ the longitudinal dispersivity [m] ( $\alpha_{L F}$ and $\alpha_{L f}$ for the fractured and fissured media respectively) and $u$ the pore velocity $\left[\mathrm{m}_{\mathrm{s}} \mathrm{s}^{-1}\right.$ ]expressed by $u=\frac{Q}{2 n \pi r h}$, where $\mathrm{n}$ is the effective porosity $\left(\mathrm{n}_{\mathrm{F}}\right.$ and $\mathrm{n}_{\mathrm{f}}$ for the 
fractured and fissured media respectively)[-], and $h$ the aquifer thickness $[m]\left(h_{F}\right.$ and $h_{f}$, for the fractured and fissured mediarespectively).

A recovery factor $(\mathrm{RF})$ is used to take into account the unexplained mass losses, where $\Delta M=\Delta M i n j * R F$ with $\Delta \mathrm{M}_{\mathrm{inj}}$ the injectedmass in the injection well.

The fate and transport of the $\mathrm{TiO}_{2} \mathrm{NPs}$ were then estimated using the previously calculated aquifer transport parameters (effective porosity, longitudinal dispersivity;Pauwels et al., 1998) and the experimental results of the NP breakthrough curve. Two specific parameters, i.e. a recovery factor and a delay term relative to $\mathrm{Br}$ behaviour, were used to characterize the $\mathrm{TiO}_{2}$ NP transfer through the schist aquiferand compared to the $\mathrm{Br}$ behavior. The concentration is equal to $0 \mathrm{~kg} \cdot \mathrm{m}^{3}$ when $t=t r-D<0$, with $\operatorname{tr}$ for the real time. Then the concentration is calculated by the equation.

\section{Results and discussion}

\subsection{Hydrological characterization of the aquifer}

Hard-rock aquifers are very complex systemsin which the role of fracture connectivity, which affects both time transfer and chemical processes, isimportant for groundwater flow and contaminant transport. In the present experiment, the test with $\mathrm{Br}$ aimed at a better characterization of the aquifer medium for evaluating the NP transfer.

After the $\mathrm{NaBr}$ injection, the flow rate in Well DNS1 was globally $2.46 \cdot 10^{-4} \mathrm{~m}^{3} \cdot \mathrm{s}^{-1}$. The recorded evolution of the $\mathrm{Br}$ concentration with time within the injection well is shown in Fig. 2. Given that renewal of the entire water volume in the well takes 8 minutes with a recirculation pumping rate of $1.4 \cdot 10^{-3} \mathrm{~m}^{3} \cdot \mathrm{s}^{-1}$, mixing is instantaneous and the $\mathrm{Br}$ concentrations rapidly became homogeneous in samples collected $65 \mathrm{~m}$ above the injection point at 70 depth $\left(\mathrm{Br}=6 \mathrm{mmol} . \mathrm{L}^{-1}\right.$ one hour after $\mathrm{Br}$ injection). That this value remained 
below the expected concentration, assuming instantaneous mixing ( $\left.45 \mathrm{mmol} . \mathrm{L}^{-1}\right)$, was most probably because the $\mathrm{Br}$ transfer towards Well DNS1 started very rapidly in the vicinity of the fracture at $70 \mathrm{~m}$ depth where the concentrated Brsolution was injected. The Br concentration decreased with time, confirming the continuous transfer of the injected solutes within the aquifer (Fig. 2). Two days after injection, the dilution factor $\left([\mathrm{Br}]_{\text {injected }} /[\mathrm{Br}]_{\text {at } j+2}\right)$ reached 18. Fig. 2 also shows that the measured $\mathrm{Br}$ concentration and the $\mathrm{EC}$ of the water are well correlated during the first week after $\mathrm{Br}$ injection. This confirms that the $\mathrm{Br}^{-}$concentration in water overrides the natural geochemical background and that EC can be used to probe its fate during this period (Revil and Glover, 1997). After 6 days, the $\mathrm{Br}$ concentration (1 $\mathrm{mmol} / \mathrm{L}$ ) was still higher than the background level.

The measured $\mathrm{Br}\left(\mathrm{mmol}^{\mathrm{L}} \mathrm{L}^{-1}\right)$ breakthrough curve in Well DNS1 is shown in Fig. 3; the time axis at day 0 represents the injection. About $31.3 \%$ of the conservative $\mathrm{Br}$ tracer was recovered at Well DNS1 over the total duration of the measurement, meaning that $68.7 \%$ of the tracer was not captured by the applied pumping flow. A temporal flow change due to the pumping stops and rainstorms is supposed to be at the origin of the small second $\mathrm{Br}$ peak. However, part of the missing $\mathrm{Br}$ could have arrived after the end of the experiment as a result of diffusion through the non-active porosity, as indicated by the EC value which still remained higher than the initial measurement after 30 days of test $\left(270>225 \mu \mathrm{S} . \mathrm{cm}^{-1}\right)$. Moreover, although the surface charge of the schist is slightly negative, the $\mathrm{Br}^{-}$ions can interact with the positive surface charges present in minor quantity such as iron oxides and oxyhydroxide. A $\mathrm{Br}$ early breakthrough is therefore not expected. Ultimately, part of the missing Br must also have been transported in pathways that do not converge towards Well DNS1.

The simulated BTC corresponds to the superposition of the transport rates through the lesser and the more conductive zones, respectively. We took into account the distance between Well F1 and Well DNS1 $(15.20 \mathrm{~m})$ and the entire aquifer thickness $(50 \mathrm{~m})$, whichincludes two media of equal thickness (25 m)as defined by Pauwels et al. (1998);one for a network of small fissures in which solute transport would be slower and the other for the 
large fissures (fractures) in which solute transport would be relatively fast, as represented by the major fracture at $70 \mathrm{~m}$ depthin Well F1. No solute exchange between the two media was taken into account. The parameters were calibrated manually and the parameters giving the best shape of the BTC and the best mass recovery are presented here. The final BTC is thus the sum of each medium's BTC. The superposition of the measured Br-BTC on the two breakthrough curves appears to be an adequate approximation of the general behaviorconfirming that the two different pathways converge towards the downstream well DNS1, which is in agreement with previous studies (Pauwels et al., 1998). The transport parameters (effective porosity and dispersivityof each medium) were then fitted to the $\mathrm{Br}$ breakthrough curvesusing a recovery factor of $31.3 \%$ as previously described. The other parameters described in Table 2 are taken from the simulation ofPauwels et al. (1998) and defined by the experiment (i.e layer thickness, injected mass, flow rate, background concentration).

Inthe Br-BTC, the estimated effective porosities in the simulated Br-BTCare low $(<1 \%)$. The calculated porosity of the slow transport medium $(0.73 \%)$ isthree times higher than that of the fast transport medium $(0.24 \%)$, in agreement with representative data for schist (de Marsilly, 1981). The longitudinal dispersivity calculated by the model for the slow transport medium is also higher than for the fast transport medium, and thisby a factor of 1.5 (i.e. 2.5 vs. $1.6 \mathrm{~m}$ ). The result can be explained by the textural heterogeneity of the schist which is characterized by a set of more or less conductive fracture and fissure zones (Dewandel et al., 2011; Maréchal et al., 2004) inducing a high heterogeneity of transport paths between the two wells; in effect, water connectivity is dependent on the geometrical properties of the fracture network. The hydraulic conductivity of the fissures in the weathered-fissured faciesis lower than that of the fissures in the fresh rockfacies due to possible closure and filling with clay materials or iron oxides. When the transport occurs through the connected fractures or larger fissures, it is relatively rapid and the dispersivity displayed bythe tracer is low. 
Conversely, transport within the small, poorly connectedand less conductive fissures is very slow and dispersivity is high. This implies a long-term restitution of the $\mathrm{Br}$ within the pumping well at very low concentrations that could remain in the range of the natural background concentration $\left(3 \mu \mathrm{mol} . \mathrm{L}^{-1}\right)$.

\subsection{Evolution of the TiO2 NP suspension in the injection well water (F1)}

During laboratory tests, $\mathrm{TiO}_{2} \mathrm{NPs}\left(0.035 \mathrm{mg} \cdot \mathrm{L}^{-1}\right)$ were diluted in MilliQ water and in groundwater from well F1. A quick aggregation was pointed out after mixing with the natural groundwater, i.e. an average size of 2780 to $4170 \mathrm{~nm}$ at $\mathrm{pH} \mathrm{7,} \mathrm{with} \mathrm{a} \mathrm{polydispersity} \mathrm{index} \mathrm{of}$ 0.5-0.6. Similarly, the hydrodynamic size of the $\mathrm{TiO}_{2} \mathrm{NPs}$ increased dramatically when diluted in the water (50 L) just collected from Well F1 (Fig. 4) as opposed to MilliQ water, with values between 1700 and $3500 \mathrm{~nm}$ (approximate mean of $3070 \mathrm{~nm}$ ) anda weakly negative zeta potential at $-13.2 \mathrm{mV}$ (electrophoretic mobility $[E M]=-0.93 \mu \mathrm{m} \mathrm{s}^{-1} \cdot \mathrm{V}^{-1} \mathrm{~cm}$; Table 3). Because of the low $\mathrm{Na}$ concentration in the Well F1 groundwater, which is significantly lower than the critical coagulation concentration of $1-4 \cdot 10^{-2} \mathrm{M}$ for $\mathrm{pH} 8$ (Solovitch et al., 2010), the rapid aggregation was probably related to the presence of significant concentrations of divalent counter-ions, in particular $\mathrm{Ca}^{2+}\left(0.31 \mathrm{mmol} . \mathrm{L}^{-1}\right)$, and to the groundwater $\mathrm{pH}$ of 6.5 6.9, which is close to the $5.5 \mathrm{pH}_{\mathrm{IEP}}$ of $\mathrm{TiO}_{2} \mathrm{NPs}$ (Belen Romanello and Fidalgo de Cortalezzi, 2013; Liu et al., 2011; Praetorius et al., 2014).

The average scattered intensity (derived count rate) recovered with each DLS size measurement in the water decreased with time, suggesting a decreasing NP concentration and thus the settling outof $\mathrm{TiO}_{2}$ NPs from the suspension(Table 3). The intensity at $1.5 \mathrm{~h}$ following the NP injection was $138650 \mathrm{kcps}$ (as against the natural groundwater background of 6645 to $9700 \mathrm{kcps}$ ); it decreased to $75900 \mathrm{kcps}$ after $16 \mathrm{~h}$ and returned to the natural background level of $6650 \mathrm{kcps}$ after $72 \mathrm{~h}$. The size distribution measured in these samples revealed a polydispersed system with the presence of aggregates larger than $1 \mu \mathrm{m}$. The 
average size decreased slightly from 3.0 to $1.3 \mu$ mduring the first 30 minutes,suggesting that the largest particles were progressively and preferentially removed from the water. Several hypotheses can be suggested to explain this trend: settling, filtering, and passage through the pumps or breakage through shearing due to the water recirculation in the well and to the vertical flowin the well (Riley et al., 2011) or the lateral flow in the fracture. But according to Stokes' law in the absence of agitation (Lamb, 1994), $6 \mu \mathrm{m}$-diameter particles would drop by only $10 \mathrm{~m}$ depth within 56 hours, assuming a mass density of $4 \mathrm{~g} \cdot \mathrm{cm}^{-3}$ for the $\mathrm{TiO}_{2}$ and a dynamic viscosity of $1.13 \cdot 10^{-3} \mathrm{~Pa} \mathrm{~s}$ at $14^{\circ} \mathrm{C}$ for the water. Thus settling of the largest aggregates under the test conditions is unlikely because the continuous circulation within the well would have enabled the large aggregates to reach shallow levels of the water column. In contrast, the shear rate induced by the fluid flow through Well F1 might have played a significant role. Considering a well of $11.2 \mathrm{~cm}$ diameter and a flow rate of $1.4 \cdot 10^{-3} \mathrm{~m}^{3} \cdot \mathrm{s}^{-1}$, the resulting shear rate would be $10 \mathrm{~s}^{-1}$. The related dissipation energy is likely to cause fragmentation and/or erosion of the largest NP aggregates that had formed (Zahnow et al., 2011) and thus to lead to the lower measured average size (Bouyer et al., 2005). Finally, the NPs were injected at the depth of a large fracture which size is unknown (Fig. 1) to limit the consequences of possible spreading in the well.

It is unlikely that natural organic matter (NOM) played a role here on the NP dispersion by creating additional steric and repulsive electrostatic forces between the NPs (Belen Romanello and Fidalgo de Cortalezzi, 2013; Chen and Elimelech, 2007; Labille and Brant, 2010; Labille et al., 2012; Praetorius et al., 2014). The apparent zeta potential of the NPs did not, in fact, evolve during the experiment (-16 mV after $1 \mathrm{~h}$ of mixing, $-14.9 \mathrm{mV}$ after $72 \mathrm{~h}$ ). Moreover, the DOC and TOC concentrations were very low compared to usual observed effects (Keller et al., 2010) and their slight decrease after the NP injection was more likely due to natural variations (e.g. 9 months before the test the DOC and TOC were $<Q L$ ).

Finally, a grey deposition observed on the well casing and piping at the end of the experiment can be attributed to $\mathrm{TiO}_{2}$ NPsattachment onto the plastic surfaces during 
passage through the pumps (recirculation and abstraction) and mixing in the well. Although this loss remains difficult to quantify, the chemical monitoring of water within the injection well proves the persistence of $\mathrm{TiO}_{2}$ NPs in the water available for transfer towards the pumping well.

\section{3 $\mathrm{TiO}_{2} \mathrm{NP}$ transport in the schist aquifer}

The measured $\mathrm{Ti}\left(\mu \mathrm{mol} \cdot \mathrm{L}^{-1}\right)$ breakthrough curve is plotted as concentrations versus time (day) in Fig. 5. Even though the NP injection occurred six days after the $\mathrm{Br}$ injection, the figure provides a comparison between the $\mathrm{Br}$ transport and that of the $\mathrm{TiO}_{2} \mathrm{NPs}$ in the hardrock aquifer. A low, but measurable, fraction of Ti ranging from $<Q L$ to $0.033 \mu \mathrm{mol}^{-\mathrm{L}^{-1}}$ was recovered 2.5 days after the NP injection in Well DNS1. The $\mathrm{TiO}_{2} \mathrm{NP}$ breakthrough curve indicates the presence of two peaks during the first 12 days after the NP injection and the appearance of a small bulge at around 16 days after injection (Fig. 5). The latter is mostly attributed to the entry of rainwater after rainfalls. Furthermore, a delay is observed between the increases in the $\mathrm{Br}$ and $\mathrm{Ti}$ concentrations in the water of Well DNS1. The chemical and physical processes responsible for NP transport in porous media are known to be very complex due to NP-NP, NP-rock and NP-indigenous particles interactions, which themselves depend on the various surface charges, the pore network structure and connectivity, the size and shape of the NP aggregates, the solid NP and rock compositions, the groundwater's chemical composition and the hydrodynamic conditions (Bouhaik et al., 2013; Dewandel et al., 2011; Petosa et al., 2010; Tufenkji and Elimelech, 2004; Yang et al., 2013).

The behavior of the $\mathrm{TiO}_{2}$ NP in the aquifer wasidentified using the CATTI software. Features that retard the NP motion, such as weak and reversible interactions of $\mathrm{TiO}_{2} \mathrm{NPs}$ with the rock and structural factors (dispersivity, porosityfor each medium), are taken into account by a delay term, whilst irreversible NP deposition (attachment, pore clogging, sedimentation)is taken into account in the mass-recovery factor. The effective porosities and the longitudinal 
dispersivitiesfor the simulated Ti-BTC were fixed from the Br-BTC modellingfor each medium. The final BTC for such a heterogeneous mediumis a superposition of the two BTCs corresponding to the two main circulation zones that were simulated by the $\mathrm{Br}$ and $\mathrm{TiO}_{2}$ BTCs. The fitted curve (Fig. 5) was obtained by applying a recovery factor of 0.1 (see Section 4.4) with a delay termof 0.58 day. This small delay termrepresenting the mass losses of $\mathrm{Ti}$ can be attributed to a part remaining unexplained as for $\mathrm{Br}$ and to the physical-chemical reactivity of the NPs likely to interact with the surrounding schist. The optimized parameters (Ti-mass recovery factor, delay) confirm that, in a given fracture/fissure, the $\mathrm{TiO}_{2} \mathrm{NPs}_{\text {were }}$ reactive and not necessarily transferred along the same pathways;unlike the conservative $\mathrm{Br}$ tracer, they do not penetrate the entire pore network during transfer, especially where the porosity is very low, due to electrostatic interactions between the NP aggregates and therockand also to the aggregate size and the hydrodynamic conditions(Solovitch et al., 2010; Huber et al., 2012). The transport behaviour of $\mathrm{TiO}_{2}$ NPscan be considered as hydrodynamic-dependent, especially when forming aggregates around $\mu \mathrm{m}$ in size. One could expect that not only would the aggregated NPs be more liable to mechanical deposition in pore spaces than the dispersed NPs, but also that they would migrate more rapidly through preferential pathways toward the farther end pointsas the capacity of large aggregates to penetrate the pore network is less than that of a single NP due to their size. The motion of suspended particles where hydrodynamic streamlines are concerned depends on their aggregation state and fractal dimensions. Porous aggregates exhibit a low drag coefficient, favouring their deposition onto surfaces, whereas individual NPs would preferentially follow streamlinesthrough the pore network (Solovitch et al., 2010; Veerapaneni and Wiesner, 1996). If this was the case in the present study, we should expect the mobile NPs to have followed preferential pathways and breakthrough more rapidly than the $\mathrm{Br}$, and at the same time be subject to reversible NP-rock attachmentthat may be reversible. These assumptions are consistent with the observed NP restitution peak, which is delayed and narrower compared to the $\mathrm{Br}$ one. 


\section{4 $\mathrm{TiO}_{2} \mathrm{NP}$ loss in the schist aquifer}

The Ti mass $(0.065 \%)$ was calculated from the sum of the Ti recovered masses overthe total amount of injected $\mathrm{Ti}(120 \mathrm{~g})$. It is in the same order of magnitude as the recovery factor $(0.1 \%)$ in the $\mathrm{TiO}_{2}$ breakthrough curve simulation. By comparison, the conservative tracer was characterized by a $\mathrm{Br}$ mass recovery factor of $31.3 \%$. As already indicated, aloss of $\mathrm{TiO}_{2}$ NPs at the injection well probably contributed to the restitution difference between the $\mathrm{Br}$ and the $\mathrm{TiO}_{2} \mathrm{NPs}$.

Different phenomena are likely to contribute to the high deposition rate of $\mathrm{TiO}_{2} \mathrm{NPs}$ along the largest and well-connected fissures. Firstly, the measured aggregation of the NPs certainly favours mechanical filtering through fissures and fractures of the schist media, implying decreasing deposition with distance from injection (Solovitch et al., 2010; Tufenkji and Elimelech, 2004; Tufenkji and Elimelech, 2005). Secondly, the charge heterogeneity of the schist due to its mineral composition is a key factor controlling the deposition of NPs on mineral surfaces (Torkzaban et al., 2010; Tufenkji and Elimelech, 2005). $\mathrm{TiO}_{2} \mathrm{NPs}$ are weakly negatively charged under the groundwater's $\mathrm{pH}$ conditions and the apparent zeta potential value of the schist is also weakly negative, although this results from a mixing of positively and negatively charged mineral surfaces. In effect, the point of zero charge of the schist's major primary and secondary minerals is low, implying negatively charged surfaces within the aquifer under the groundwater $\mathrm{pH}$ conditions (6.5-6.9). Both the fresh and the weathered-fissured schist are made up of quartz ( $\mathrm{pH}_{\mathrm{PzC}}=2-3$ [Leroy et al., 2013]), K-feldspar $\left(\mathrm{pH}_{\mathrm{PZC}}=2.0\right.$ to 2.4$)$, kaolinite $\left(\mathrm{pH}_{\mathrm{PZC}}=2-4\right.$ [Leroy and Revil, 2004; Tombacz and Szekeres, 2006]) and chlorite $\left(\mathrm{pH}_{\mathrm{PZC}}=3\right.$ [Yin et al., 2013]), as well as other minerals, such as iron oxidesand oxyhydroxides, characterized by a basic $\mathrm{pH}_{\mathrm{PzC}}$ close to 8 (Dzombak and Morel, 1990). These latter minerals are positively charged at a $\mathrm{pH}$ of around 7 and are likely to favour electrostatic attraction between the NPs and the Fe-oxide surfaceswith a resultant deposition of the negatively charged NPs. The iron oxyhydroxide phases are known to have 
an important adsorption potential due to their high specific surface area (Dzombak and Morel, 1990) and sowe can assume that a certain amount of $\mathrm{TiO}_{2} \mathrm{NPs}$ could also be attachedby electrostatic attraction onto the Fe oxyhydroxides. The local geochemical conditions of the schist aquifer, favouring denitrification and subsequent iron oxyhydroxide precipitation or presence ascolloids in the main water pathways due to pyrite and $\mathrm{Fe}^{2+}$ oxidation by nitrates(Pauwels et al, 2000), are likely to enhance attenuation mechanisms by reducing contamination levels during the NPs migration through the aquifer.

$\mathrm{TiO}_{2}$ NPs can also be favourably attachedin the weathered parts of the aquifer; in the present case theweathered saprolite facies of the schist has a porosity that is solicited by pumping in Well DNS1. The weathering products of the saprolite are likely to give different reactions; for example, attachmentof the NPs will be enhanced by the presence of iron oxyhydroxides, whereas electrostatic repulsion of the NPs will be favoured by clay minerals that are mostly negatively charged at a $\mathrm{pH}$ of around 7 (Fig. 1). Although the role played by the weathered part of the aquifer was not studied due to the NPs being injected at a depth of $70 \mathrm{~m}$ in the aquifer, the unsaturated weathered facies and its thickness will nevertheless play a significant role as regards the aquifer's vulnerability by reducing the downward migration speed of water and contaminants through the medium (Brouyère et al., 2004).Finally, a more detailed study is underway to explore the role of the different minerals with respect to the attachmentprocess, with experiments of $\mathrm{TiO}_{2} \mathrm{NP}$ circulation through fresh schist cores from the same aquifer (Ollivier et al., in prep).

\section{Conclusions}

The physical and chemical processes responsible for NP transport in porous media are very complex due to NP-NP and NP-rock interactions, which themselves depend on the various surface charges, the pore network structure and connectivity, the groundwater's chemical composition and the hydrodynamic conditions. 
Our small-scale tracer experiment conducted in a schist aquifer is an attempt to understand the physical and chemical processes occurring should $\mathrm{TiO}_{2} \mathrm{NPs}$ happen to penetrate a hard-rock aquifer. One of the major results is that the $\mathrm{TiO}_{2} \mathrm{NPs}$ were found to be mobile, transferringin an aggregate form through the conductive zones of a heterogeneous schist. During the transfer, a large amount of the NPs was also deposited onto the rock surface through sedimentation, clogging and attachment. The natural denitrification process occurring in the aquifer is responsible for the presence of precipitated and positively charged iron oxyhydroxides in the main flow pathsthat are capable of adsorbing a large amount of negatively charged $\mathrm{TiO}_{2}$ NPs. It is worth noting that NP attachmentcan bereversible due to the possible evolution of the surface charge of the different minerals constituting the schist rock according to the environmental conditions. For instance, any modification of the aquifer's chemical conditions may impact the $\mathrm{pH}$ and the denitrification process, as well as the heterogeneity of the schist. Regional changes in agricultural practicesthat lead to a lower nitrate input could typically play a role in $\mathrm{TiO}_{2} \mathrm{NP}$ transfer.

As a first approach, our workconfirms both the potential for $\mathrm{TiO}_{2} \mathrm{NPs}$ to be transported in natural groundwater and the vulnerability of the hard-rock aquifer. Further investigations, currentlyin preparation, are required for a better understanding of the processes occurring during NP transfer, including the role of the different minerals with respect to sorption processes. Other questions to be addressed concern the evolution of NP aggregates during transport due to dilution and interaction with organic matter or to shearing energy. Longer experiments aimingat studying the release of NPs deposited within the aquifer are also required. The increased knowledge from such field experiments is also dependent on the evolution of analytical techniques both for NP measurements, particularly at very low NP concentrations, and on-site measurements.

\section{Acknowledgments}


This work was supported by the French National Agency for Research (ANR; grant number PNANO ANR-07-NANO-035) and the BRGM through the AquaNano project. C. Crouzet of the BRGM laboratories is thanked for providing experimental and monitoring facilities, and T. Laurioux is thanked for the ICP-MS measurements. We also kindly thank Dr. Natacha Solovitch for her help with streaming potential measurements, as well as the three anonymous reviewers for their thorough revisions of the manuscript. We are grateful to Patrick Skipwith for revising and editing the English text.

\section{References}

Auffan, M., Rose, J., Wiesner, M.R. and Bottero, J.-Y., 2009. Chemical stability of metallic nanoparticles: A parameter controlling their potential cellular toxicity in vitro. Environmental Pollution, 157(4): 1127-1133.

Ayraud, V.,Aquilina, L., Labasque, T., Pauwels, H., Molenat, J., Pierson-Wickmann, AC.,Durand, V., Bour, O., Tarits, C., Le CVorre, P., Fourre, E., Merot, P. and Davy, P., 2008. Compartmentalization of physical and chemical properties in hard-rock aquifers deduced from chemical and groundwater age analyses. Applied Geochemistry, 23(9): 2686-2707.

Belen Romanello, M. and Fidalgo de Cortalezzi, M.M., 2013. An experimental study on the aggregation of $\mathrm{TiO} 2$ nanoparticles under environmentally relevant conditions. Water Research, 47(12): 3887-3898.

Ben-Moshe, T., Dror, I. and Berkowitz, B., 2010. Transport of metal oxide nanoparticles in saturated porous media. Chemosphere, 81(3): 387-393.

Bennett, P., He, F., Zhao, D.Y., Aiken, B. and Feldman, L., 2010. In situ testing of metallic iron nanoparticle mobility and reactivity in a shallow granular aquifer. Journal of Contaminant Hydrology, 116(1-4): 35-46.

Bouhaik, I.S., Leroy, P., Ollivier, P., Azaroual, M. and Mercury, L., 2013. Influence of surface conductivity on the apparent zeta potential of $\mathrm{TiO} 2$ nanoparticles: Application to the modeling of their aggregation kinetics. Journal of Colloid and Interface Science, 406: 75-85.

Bouyer, D., Coufort, C., Liné, A. and Do-Quang, Z., 2005. Experimental analysis of floc size distributions in a 1-L jar under different hydrodynamics and physicochemical conditions. Journal of Colloid and Interface Science, 292(2): 413-428.

Boisson, A.,de Anna, A., Bour, O., Le Borgne, T., Labasque, T. and Aquilina, L., 2013. Reaction chain modeling of denitrification reactions during a push-pull test. Journal of Contaminant Hydrology, 148(0): 1-11.

Brant, J., Lecoanet, H. and Wiesner, M.R., 2005. Aggregation and deposition characteristics of fullerene nanoparticles in aqueous systems. Journal of Nanoparticle Research, 7(4-5): 545-553.

Brouyère, S., Dassargues, A. and Hallet, V., 2004. Migration of contaminants through the unsaturated zone overlying the Hesbaye chalky aquifer in Belgium: a field investigation. Journal of Contaminant Hydrology, 72(1-4): 135-164. 
Chen, G., Liu, X. and Su, C., 2011. Transport and Retention of TiO2 Rutile Nanoparticles in Saturated Porous Media under Low-Ionic-Strength Conditions: Measurements and Mechanisms. Langmuir, 27(9): 5393-5402.

Chen, G., Liu, X. and Su, C., 2012. Distinct Effects of Humic Acid on Transport and Retention of TiO2 Rutile Nanoparticles in Saturated Sand Columns. Environmental Science \& Technology, 46(13): 7142-7150.

Chen, K.L. and Elimelech, M., 2007. Influence of humic acid on the aggregation kinetics of fullerence (C60) nanoparticles in monovalent and divalent electrolyte solutions. Journal of Colloid and Interface Science, 309: 126-134.

Crespy, A., Boleve, A. and Revil, A., 2007. Influence of the Dukhin and Reynolds numbers on the apparent zeta potential of granular porous media. Journal of Colloid and Interface Science, 305(188-194).

de Marsilly, G., 1981. Hydrogéologie quantitative, Ed. Masson, Paris, 215 p pp.

Dewandel, B., Lachassagne, P., Wyns, R., Maréchal, J. and Krishnamurthy, N., 2006. A generalized 3-D geological and hydrogeological conceptual model of granite aquifers controlled by single or multiphase weathering. Journal of Hydrology, 330 ((1-2)): 260284.

Dewandel, B., Lachassagne, P., Zaidi, F.K. and Chandra, S., 2011. A conceptuel hydrodynamic model of a geological discontinuity in hard rock aquifer: Example of a quartz reef in granitic terrain in South India. Journal of Hydrology, 405: 474-487.

Dzombak, D.A. and Morel, F.M.M. (Editors), 1990. Surface Complexation Modeling: Hydrous Ferric Oxide.

Elliott, D.W. and Zhang, W.-x., 2001. Field Assessment of Nanoscale Bimetallic Particles for Groundwater Treatment. Environmental Science \& Technology, 35(24): 4922-4926.

Fang, J., Xu, M.-j., Wang, D.-j., Wen, B. and Han, J.-y., 2013. Modeling the transport of TiO2 nanoparticle aggregates in saturated and unsaturated granular media: Effects of ionic strength and $\mathrm{pH}$. Water Research, 47(3): 1399-1408.

Fouqueray, M., Noury, P., Dherret, L., Chaurand, P., Abbaci, K., Labille, J., Rose, J. and Garric, J., 2013. Exposure of juvenile Danio rerio to aged TiO2 nanomaterial from sunscreen. Environmental Science and Pollution Research, 20(5): 3340-3350.

French, R.A.,Jacobson, A.R., Isley, S.L., Penn, R.L. and Baveye, P.C., 2009. Influence of ionic strength, $\mathrm{pH}$, and cation valence on aggregation kinetics of titanium dioxide nanoparticles. Environmental Science \& Technology, 43(5): 1354-1359.

Gaya, U.I. and Abdullaha, A.H., 2008. Heterogeneous photocatalytic degradation of organic contaminants over titanium dioxide: a review of fundamentals, progress and problems Journal of Photochemistry and Photobiology C: Photochemistry Reviews, 9(1): 1-12.

Ghosh, M., Bandyopadhyay, M. and Mukherjee, A., 2010. Genotoxicity of titanium dioxide (TiO2) nanoparticles at two trophic levels: Plant and human lymphocytes. Chemosphere, 81(10): 1253-1262.

Godinez, I.G. and Darnault, C.J.G., 2011. Aggregation and transport of nano-TiO2 in saturated porous media: effects of $\mathrm{pH}$, surfactants and flow velocity. Water Research 45, 45: 839-851.

Gondikas, A.P.,von der Kammer, F., Reed, R.B., Wagner, S., Ranville, J.F. and Hofmann, T.,2014. Release of TiO2 Nanoparticles from Sunscreens into Surface Waters: A One-Year Survey at the Old Danube Recreational Lake. Environmental Science \& Technology, 48(10): 5415-5422.

Guihéneuf, N.,Boisson, A., Bour, O., Dewandel, B., Perrin, J., Dausse, A., Viossanges, M., Chandra, S., Ahmed, S. and Maréchal, J.C., et al., 2014. Groundwater flows in weathered crystalline rocks: Impact of piezometric variations and depth-dependent fracture connectivity. Journal of Hydrology, 511: 320-334.

Guzman, K.A.D., Taylor, M.R. and Banfield, J.F., 2006. Environmental risks of nanotechnology: National nanotechnology initiative funding, 2000-2004. Environmental Science \& Technology, 40(5): 1401-1407. 
Holbrook, R.D.,Motabar, D., Quinones, O., Standford, B., Vanderford, B. and Moss, D., 2013. Titanium distribution in swimming pool water is dominated by dissolved species. Environmental Pollution, 181(0): 68-74.

Huber, F.,Enzmann, F., Wenka, A., Bouby, M., Dentz, M. and Schäfer, T., 2012. Natural micro-scale heterogeneity induced solute and nanoparticles retardation in fractured crystalline rock. Journal of Contaminant Hydrology, 133: 40-50.

IARC, 2006. Agents Classified by the IARC Monographs. WHO. Volumes 1-109.

Jaunat, J.,Huneau, F., Dupuy, A., Celle-Jeanton, H., Vergnaud-Ayraud, V., Aquilina, T., Labasque, T. and Le Coustumer, P, 2012. Hydrochemical data and groundwater dating to infer differential flowpaths through weathered profiles of a fractured aquifer. Applied Geochemistry, 27(10): 2053-2067.

Johnson, A.C.,Bowes, M.J., Crossley, A., Jarvie, H.P., Jurkschat, K., Jürgens, M.D., Lawlor, A.J., Park, B., Rowland, P., Spurgeon, D., Svendsen, C., Thompson, I.P., Barnes, R.J., Williams, R.J and Xu, N., 2011. An assessment of the fate, behaviour and environmental risk associated with sunscreen $\mathrm{TiO} 2$ nanoparticles in UK field scenarios. Science of The Total Environment, 409(13): 2503-2510.

Kaegi, R.,Ulrich, A., Sinnet, B., Vonbank, R., Wichser, A., Simmler, H., Brunner, S., Vonmont, H., Burkhardt, M. and Boller, M., 2008. Synthetic TiO2 nanoparticle emission from exterior facades into the aquatic environment. Environmental Pollution, 156(2): 233-239.

Keller, A.A.,Wang, H., Zhou, D., Lenihan, S.H., Cherr, D., Cardinale, B.J., Miller, R. and Ji, Z., 2010. Stability and Aggregation of Metal Oxide Nanoparticles in Natural Aqueous Matrices. Environmental Science \& Technology, 44(6): 1962-1967.

Labille, J. and Brant, J., 2010. Stability of nanoparticles in water. Nanomedicine, 5(6): 985998.

Labille, J., Pelinovskaya, N., Botta, C., Bottero, J.Y. and Masion, A., 2012. Fate of Manufactured Nanoparticles in Aqueous Environment: Effects and Persistence of the Surface Functionalization in a Lifecycle Perspective. Example of Nano-TiO2 Used in Sunscreens, Encyclopedia of Nanotechnology. Springer Science+Business Media B.V.

Lamb, H., 1994. Hydrodynamics (6th edition). Cambridge University Press, England: 768 p.

Leroy, P. and Revil, A., 2004. A triple layer model of the surface electrochemical properties of clay minerals. Journal of Colloid Interface Science, 270(2): 371-380.

Leroy, P., Tournassat, C. and Bizi, M., 2011. Influence of surface conductivity on the apparent zeta potential of $\mathrm{TiO} 2$ nanoparticles. Journal of Colloid and Interface Science, 356(2): 442-453.

Leroy, P., Devau, N., Revil, A. and Bizi, M., 2013. Influence of surface conductivity on the apparent zeta potential of amorphous silica nanoparticles. Journal of Colloid and Interface Science, 410: 81-93.

Lin, D., Tian, X., Wu, F. and Xing, B., 2010. Fate and Transport of Engineered Nanomaterials in the Environment. J. Environ. Qual., 39(6): 1896-1908.

Liu, H.T.,Ma, L., Zhaq, J., Yan, J., Ruan, J. and Hong, F., 2009. Biochemical Toxicity of Nano-anatase TiO2 Particles in Mice. Biological Trace Element Research, 129(1-3): 170-180.

Liu, X.Y., Chen, G.X. and Su, C.M., 2011. Effects of material properties on sedimentation and aggregation of titanium dioxide nanoparticles of anatase and rutile in the aqueous phase. Journal of Colloid and Interface Science, 363(1): 84-91.

Lowry, G.V., Hotze, E.M., Bernhardt, E.S., Dionysiou, D.D., Pederson, J.A., Wiesner, M.R. and Xing, B., 2010. Environmental Occurrences, Behavior, Fate, and Ecological Effects of Nanomaterials: An Introduction to the Special Series. Journal of Environmental Quality, 39(6): 1867-1874.

Ma, L.L., Zhao, J.F., Wang, J., Liu, J., Duan, Y.M., Liu, H.T., Li, N., Yan, J.Y., Ruan, J., Wang, H. and Hong, F.S.,2009. The Acute Liver Injury in Mice Caused by NanoAnatase TiO2. Nanoscale Research Letters, 4(11): 1275-1285. 
Maréchal, J.C., Dewandel, B. and Subrahmanyam, K., 2004. Use of hydraulic tests at different scales to characterize fractures. Water Resources Research 40(40): 17.

Martelat, A. and Lachassagne, P., 1995. Basin versant représentatif du Coët Dan (Naizin, Morbihan), hydrologie : détermination des caractéristiques hydrodynamiques du système aquifère au lieu-dit le Stimoes. Unpublished BRGM report, $\mathrm{n}^{\circ}$ R38474DR/HYT95, 54 p.

Moore, M.N., 2006. Do nanoparticles present ecotoxicological risks for the health of the aquatic environment? Environment International, 32(8): 967-976.

Pauwels, H., Kloppmann, W., Foucher, J.C., Martelat, A. and Fritsche, V., 1998. Field tracer test for denitrification in a pyrite-bearing schist aquifer. Applied Geochemistry, 13(6): 767-778.

Pauwels, H., Foucher, J.C. and Kloppmann, W., 2000. Denitrification and mixing in a schist aquifer: influence on water chemistry and isotopes. Chemical Geology, 168(3-4): 307324.

Pauwels, H., Négrel, P., Dewandel, B., Perrin, J., Mascré, C., Roy, S. and Ahmed, S., 2015. Hydrochemical borehole logs characterizing fluoride contamination in a crystalline aquifer (Maheshwaram, India). Journal of Hydrology, 525(0): 302-312.

Pellerin, J. and Van Vliet-Lanoe, B., 1994. Cadre géomorphologique du bassin du Coët Dan et du Haut Evel (Morbihan): Rapport sur les travaux de cartographie et de stratigraphie. Unpublisched report, University of Brest.

Pena, M., Meng, X.G., Korfiatis, G.P. and Jing, C.Y., 2006. Adsorption mechanism of arsenic on nanocrystalline titanium dioxide. Environmental Science \& Technology, 40(4): 1257-1262.

Petosa, A.R., Jaisi, D.P., Quevedo, I.R., Elimelech, M. and Tufenkji, N., 2010. Aggregation and Deposition of Engineered Nanomaterials in Aquatic Environments: Role of Physicochemical Interactions. Environmental Science \& Technology, 44(17): 65326549.

Petosa, A.R., Brennan, S.J., Rajput, F. and Tufenkji, N., 2012. Transport of two metal oxide nanoparticles in saturated granular porous media: Role of water chemistry and particle coating. Water Research, 46(4): 1273-1285.

Praetorius, A.,Labille, J., Scheringer, M., Thill, A., Hungerbühler, K. and Bottero, J-Y., 2014. Heteroaggregation of Titanium Dioxide Nanoparticles with Model Natural Colloids under Environmentally Relevant Conditions. Environmental Science \& Technology, 48(18): 10690-10698.

Reijnders, L., 2009. The release of $\mathrm{TiO} 2$ and $\mathrm{SiO} 2$ nanoparticles from nanocomposites. Polymer Degradation and Stability, 94(5): 873-876.

Revil, A. and Glover, P.W.J., 1997. Theory of ionic-surface electrical conduction in porous media. Physical Review B, 55(3): 1757-1773.

Riley MS, Tellam JH, Greswell RB, Durand V, Aller MF. Convergent tracer tests in multilayered aquifers: The importance of vertical flow in the injection borehole. Water Resources Research 2011; 47: n/a-n/a.

Robichaud, C.O., Uyar, A.E., Darby, M.R., Zucker, L.G. and Wiesner, M.R., 2009. Estimates of Upper Bounds and Trends in Nano-TiO2 Production As a Basis for Exposure Assessment. Environmental Science \& Technology, 43(12): 4227-4233.

Santaella, C.,Allainmat, B., Simonet, F., Chanéac, C., Labille, J., Auffan, M., Rose, J. and Achouak, W.,2014. Aged TiO2-Based Nanocomposite Used in Sunscreens Produces Singlet Oxygen under Long-Wave UV and Sensitizes Escherichia coli to Cadmium. Environmental Science \& Technology, 48(9): 5245-5253.

Sauty, J.P., 1989. Computer Aided-Tracer Tests Interpretation. L'interpretation des tracages assistée par ordinateur. Mode d'emploi de CATTI. Version 2.0. Logiciel distribue par IGWMC (International Groundwater Modeling Center).

Sauty, J.P., Kinzelbach, W. and Voss, A., 1992. CATTI, Computer Aided Tracer Test Interpretation Program Documentation. BRGM - Gesamthochschule Kassel Universität: 64 p. 
Shih, Y.-h., Zhuang, C.-m., Peng, Y.-h., Lin, C.-h. and Tseng, Y.-m., 2012. The effect of inorganic ions on the aggregation kinetics of lab-made $\mathrm{TiO} 2$ nanoparticles in water. Science of The Total Environment, 435: 446-452.

Solovitch, N.,Labille, J., Rose, J., Chaurand, P, Borschneck, D. and Wiesner, M, 2010. Concurrent Aggregation and Deposition of TiO2 Nanoparticles in a Sandy Porous Media. Environmental Science \& Technology, 44(13): 4897-4902.

Su, C.,Puls, R.W., Krug, T.A., Watling, M.T., O'Hara, S.K., Quinn, J.W. and Ruiz, N.E., 2013. Travel distance and transformation of injected emulsified zerovalent iron nanoparticles in the subsurface during two and half years. Water research, 47: 40954106.

Tarits, C.,Aquilina, L., Ayraud, V., Pauwels, H., Davy, P., Touchard, F. and Bour, O., 2006. Oxido-reduction sequence related to flux variations of groundwater from a fractured basement aquifer (Ploemeur area, France). Applied Geochemistry, 21(1): 29-47.

Tombacz, E. and Szekeres, M., 2006. Surface charge heterogeneity of kaolinite in aqueous suspension in comparison with montmorillonite. Applied Clay Science, 34: 105-124.

Torkzaban, S., Kim, Y., Mulvihill, M., Wan, J. and Tokunaga, K., 2010. Transport and deposition of functionalized CdTe nanoparticles in saturated porous media. Journal of Contaminant Hydrology 118: 208-217.

Tufenkji, N. and Elimelech, M., 2004. Deviation from the classical colloid filtration theory in the presence of repulsive DLVO interactions. Langmuir, 20(25): 10818-10828.

Tufenkji, N. and Elimelech, M., 2005. Breakdown of colloid filtration theory: Role of the secondary energy minimum and surface charge heterogeneities. Langmuir, 21(3): 841-852.

Veerapaneni, S. and Wiesner, M.R., 1996. Hydrodynamics of fractal aggregates with radially varing permeability. J. Colloid Interface Sci., 177: 45-57.

Wiesner, M.R., Lowry, G.V., Alvarez, P., Dionysiou, D. and Biswas, P., 2006. Assessing the Risks of Manufactured Nanomaterials. Environmental Science \& Technology, 40(14): 4336-4345.

Yang, X., Deng, S. and Wiesner, M.R., 2013. Comparison of enhanced microsphere transport in an iron-oxide-coated porous medium by pre-adsorbed and co-depositing organic matter. Chemical Engineering Journal, 230: 537-546.

Yin, X., Yan, L., Liu, J., Xu, Z. and Miller, J.D., 2013. Anisotropic surface charging of chlorite surfaces. Clays and Clay Minerals, 61(2): 152-164.

Zahnow, J.C., Maerz, J. and Feudel, U., 2011. Particle-based modeling of aggregation and fragmentation processes: Fractal-like aggregates. Physica D: Nonlinear Phenomena, 240(9-10): 882-893.

Zhang, Y., Chen, Y., Westerhoff, P. and Crittenden, J., 2009. Impact of natural organic matter and divalent cations on the stability of aqueous nanoparticles. Water Research, 43(17): 4249-4257. 


\section{Figure caption}

Fig.1: Cross section illustrating the injection well F1 and the downstream pumping well DNS1 during the tracer test experiment (adapted from Pauwels et al., 1998). The diagram highlights the presence of a deep major fracture at $70 \mathrm{~m}$ depth in Well F1 (thick black line) and the main expected $\mathrm{Br}$ and NP pathways.

Fig.2: Measured $\mathrm{Br}$ concentration (mmol. $\mathrm{L}^{-1}$ ) in Well $\mathrm{F} 1$ groundwater versus time during the Br-tracer test. "EC" stands for electrical conductivity. The Br geochemical background value corresponding is $3 \cdot 10^{-3} \mathrm{mmol} . \mathrm{L}^{-1}$.

Fig.3: Experimental data and modelling of $\mathrm{Br}$ concentrations versus time in the downstream pumping well, DNS1. The Br geochemical background value is $3 \cdot 10^{-3} \mathrm{mmol}^{-1}$ (in grey).

Fig.4: Size distribution of the $\mathrm{TiO}_{2}$ NPs in MilliQ water, in the injection solution, and in Well F1 groundwater after injection.

Fig.5: Experimental data and modelling of Ti concentrations versus time in the downstream Well DNS1. The Tigeochemical background value is $0.002 \mu \mathrm{mol} . \mathrm{L}^{-1}$ (indicated in grey) and the quantification limit is $0.002 \mathrm{Ti} \mu \mathrm{mol} . \mathrm{L}^{-1}$.

\section{Table list}


Table 1: Apparent physical and chemical composition of the groundwater in wells F1 (injection) and DNS1 (pumping). $\mathrm{TiO}_{2} \mathrm{NP}$ injection was made 6.1 days after Br injection.

\begin{tabular}{|c|c|c|c|c|c|c|c|c|c|c|c|c|c|c|c|c|}
\hline Well & $\begin{array}{c}\mathrm{EC} \\
\left(25^{\circ} \mathrm{C}\right) \\
\mu \mathrm{S}_{1} \mathrm{~cm}\end{array}$ & $\mathrm{pH}$ & $\mathrm{T}^{\circ} \mathrm{C}$ & $\begin{array}{c}\text { Dissol } \\
\text { ved } \\
\mathrm{O}_{2} \\
\mathrm{mg} \cdot \mathrm{L}^{-} \\
\mathrm{L}_{\mathrm{L}}\end{array}$ & $\begin{array}{l}\text { Alk, } \\
\text { meq. } \text { L }^{-1}\end{array}$ & $\underset{\mathrm{ma}}{\mathrm{Nal} . \mathrm{L}^{-1}}$ & $\underset{\substack{\mathrm{K} \\
\mathrm{mmol}^{-1}}}{.}$ & $\begin{array}{c}\mathrm{Ca} \\
\mathrm{mmol} . \mathrm{L}^{-1}\end{array}$ & $\underset{\mathrm{mmol} \mathrm{L}^{-1}}{\mathrm{Mg}}$ & $\begin{array}{c}\mathrm{Cl} \\
\mathrm{mmol} \cdot \mathrm{L}^{-1}\end{array}$ & $\begin{array}{c}\mathrm{NO}_{3} \\
\mathrm{Mmol}^{-1} \mathrm{~L}^{-1}\end{array}$ & $\begin{array}{c}\mathrm{SO}_{4} \\
\mathrm{mmol}^{-1} .\end{array}$ & $\underset{\mathrm{L}^{-1}}{\mathrm{Ti}}$ & $\begin{array}{c}\mathrm{Br} \\
\mu \mathrm{mol} \\
. \mathrm{L}^{-1}\end{array}$ & $\begin{array}{c}\text { TOC } \\
\text { mmol.L' }\end{array}$ & $\begin{array}{c}\mathrm{DOC} \\
\text { Mmol. } \\
\mathrm{L}^{-1} \mathrm{C}\end{array}$ \\
\hline $\begin{array}{l}\mathrm{F} 124 \mathrm{~h} \\
\text { before } \mathrm{Br} \\
\text { injection }\end{array}$ & 225 & 6.94 & 12.4 & 0.7 & 1.08 & 0.70 & 0.03 & 0.31 & 0.40 & 0.72 & $<0.008$ & 0.25 & 0.002 & 3.7 & 0.2 & 0.14 \\
\hline $\begin{array}{c}\text { F1 1h } \\
\text { before NPs } \\
\text { injection }\end{array}$ & 272 & 6.84 & 13 & 0.87 & & 1.01 & 0.03 & 0.31 & 0.40 & - & $<0.008$ & - & 0.001 & 942 & 0.06 & 0.06 \\
\hline $\begin{array}{c}\mathrm{F} 1 \\
\text { 16h after } \\
\text { NPs } \\
\text { injection }\end{array}$ & 282 & 6.65 & 13.7 & 3.06 & 0.93 & 1.12 & 0.03 & 0.32 & 0.41 & 0.81 & 0.008 & 0.27 & - & 434 & 0.06 & 0.06 \\
\hline $\begin{array}{c}\text { DNS1 } \\
\text { 24h before } \\
\text { Br injection }\end{array}$ & 210 & 6.54 & 13.7 & 5.9 & 0.71 & 0.75 & 0.03 & 0.24 & 0.38 & 0.76 & 0.034 & 0.28 & 0.002 & 3.0 & $<0.04$ & $<0.04$ \\
\hline $\begin{array}{l}\text { DNS1 } 16 \mathrm{~h} \\
\text { after NPs } \\
\text { injection }\end{array}$ & 221 & 6.39 & 13.2 & 6.1 & 0.72 & 0.78 & 0.03 & 0.24 & 0.38 & 0.76 & 0.016 & 0.27 & 0.001 & 21 & $<0.04$ & $<0.04$ \\
\hline
\end{tabular}


Table 2: Parameters used into the CATTI model to simulate $\mathrm{Br}$ and Ti BTCs. For the mass, 3 $\mathrm{kg}$ of $\mathrm{NaBr}$ were expressed as $\mathrm{Br}=3 \mathrm{~kg}{ }^{*} \mathrm{M}_{\mathrm{Br}} /\left(\mathrm{M}_{\mathrm{Br}}+\mathrm{M}_{\mathrm{Na}}\right)=3{ }^{*} 79.9 /(79.9+22.99)=2.33 \mathrm{~kg}$ of $\mathrm{Br}$ homogeneously distributed in both media. For $\mathrm{Ti}, 0.2 \mathrm{~kg}$ of $\mathrm{TiO}_{2}$ were expressed as $\mathrm{Ti}=$ $0.12 \mathrm{~kg}$ homogeneously distributed in both media. A slight variation of the flow rate was noticed during the experiment.

\begin{tabular}{|c|c|c|c|c|c|c|c|c|c|}
\hline & & Flow & Mass & $\begin{array}{c}\text { Thicknes } \\
\text { s of } \\
\text { eachlayer }\end{array}$ & $\begin{array}{l}\text { Effective } \\
\text { porosity }\end{array}$ & $\begin{array}{c}\text { Longitudina } \\
\text { I } \\
\text { dispersivity }\end{array}$ & $\begin{array}{c}\text { Initial } \\
\text { concentratio } \\
\mathrm{n}\end{array}$ & $\begin{array}{l}\text { Recover } \\
y \text { factor }\end{array}$ & Delay \\
\hline & & m3.s-1 & $\mathrm{kg}$ & $\mathrm{m}$ & - & $\mathrm{m}$ & $\mathrm{kg} \cdot \mathrm{m}-3$ & & $\mathrm{~s}$ \\
\hline $\begin{array}{l}B \\
r\end{array}$ & $\begin{array}{c}\text { Layer 1 } \\
\text { Fissure - } \\
\text { lowpermeabilit } \\
y\end{array}$ & $2.46 \cdot 10-4$ & 1.165 & 25 & $7.26 \cdot 10-3$ & 2.45 & 0.00095 & 0.313 & 0 \\
\hline & $\begin{array}{c}\text { Layer } 2 \\
\text { Fracture - high } \\
\text { permeability }\end{array}$ & $2.46 \cdot 10-4$ & 1.165 & 25 & $2.38 \cdot 10-3$ & 1.63 & 0.00095 & 0.313 & 0 \\
\hline $\mathbf{T i}$ & $\begin{array}{c}\text { Layer } 1 \\
\text { Fissure - } \\
\text { lowpermeabilit } \\
y\end{array}$ & $2.33 \cdot 10-4$ & 0.06 & 25 & $7.26 \cdot 10-3$ & 2.45 & 0 & 0.001 & $5 \cdot 104$ \\
\hline & $\begin{array}{c}\text { Layer } 2 \\
\text { Fracture - high } \\
\text { permeability }\end{array}$ & $2.33 \cdot 10-4$ & 0.06 & 25 & $2.38 \cdot 10-3$ & 1.63 & 0 & 0.001 & $5 \cdot 104$ \\
\hline
\end{tabular}

Table 3: Apparent zeta potential, electrophoretic mobility, $\mathrm{pH}$, electrical conductivity $(E C)$, derived count rate, $\mathrm{Z}$ average and $\mathrm{Pdl}$ for size measurements before and after $\mathrm{TiO}_{2} \mathrm{NP}$ injection in Well F1.

\begin{tabular}{|c|c|c|c|c|c|c|c|}
\hline Sample & $\begin{array}{c}\text { Apparent zeta } \\
\text { potential, } \\
\mathrm{mV}\end{array}$ & $\begin{array}{c}\text { Electrophoretic } \\
\text { mobility, } \\
\mu \mathrm{m} \mathrm{s}^{-1} \mathrm{~V}^{-1} \mathrm{~cm}\end{array}$ & $\mathrm{pH}$ & $\begin{array}{c}\mathrm{EC} \\
\left(\mathrm{mS} . \mathrm{cm}^{-}\right. \\
\left.{ }^{\prime}\right)\end{array}$ & $\begin{array}{c}\text { Derived } \\
\text { Count rate } \\
\text { (kcps) }\end{array}$ & $\begin{array}{c}\text { Z- } \\
\text { average } \\
(\mathrm{mm})\end{array}$ & Pdl \\
\hline TiO2 NPs (uls) in MilliQ water & 44.8 & 3.17 & 3.9 & 0.09 & $3,479,978$ & 136 & 0.29 \\
\hline Initial F1 water & & & & & $\begin{array}{c}6,645- \\
9,700 \\
\end{array}$ & 5,858 & 1 \\
\hline $\mathrm{TiO}_{2} 5$ min after mixing with $\mathrm{F} 1$ & -13.2 & -0.93 & 6.7 & 0.28 & 830,067 & 3,074 & 0.34 \\
\hline $\begin{array}{c}\mathrm{TiO}_{2} 1 \mathrm{~h} 20 \text { min after mixing with } \\
\text { F1 water }\end{array}$ & & & & & 481,860 & 2,319 & 0.43 \\
\hline $1 \mathrm{~h}$ after injection & -15.6 & -1.11 & 6.9 & 0.26 & 138652 & 1,189 & 0.33 \\
\hline $4 \mathrm{~h}$ after injection & -16.0 & -1.14 & & 0.27 & 175,260 & 1,420 & 0.40 \\
\hline $16 \mathrm{~h}$ after injection & -14.5 & -0.99 & 6.6 & 0.26 & 75,900 & 1,038 & 0.31 \\
\hline $19 \mathrm{~h}$ after injection & -15.9 & -1.12 & 6.5 & 0.26 & 59,970 & 935 & 0.33 \\
\hline $72 \mathrm{~h}$ after injection & -14.9 & -1.09 & & 0.28 & $\begin{array}{l}6,650- \\
8,700\end{array}$ & 1,351 & 0.76 \\
\hline fter injection & -14.9 & -1.05 & & 0.26 & 5,000 & 2915 & 1 \\
\hline
\end{tabular}

